\title{
ANALYSIS OF SEAFLOOR DEPTH ANOMALIES BETWEEN THE ASCENSION AND ST. HELENA ISLANDS, SOUTH ATLANTIC
}

\author{
Marisa Makler ${ }^{1,2}$ and Sidney Luiz de Matos Mello ${ }^{1}$ \\ Recebido em 23 março, 2006 / Aceito em 26 abril, 2007 \\ Received on March 23, 2006 / Accepted on April 26, 2007
}

\begin{abstract}
Observed seafloor depths from $12 \mathrm{kHz}$ bathymetry coupled with seafloor spreading magnetic anomalies were used to obtain depth anomalies across the Mid-Atlantic ridge axis between $2^{\circ} \mathrm{S}$ and $18^{\circ} \mathrm{S}$. The theoretical seafloor depths were calculated from the plate cooling model and crustal ages depicted from seafloor spreading magnetic anomalies between 0 to $25 \mathrm{Ma}$. We noticed that the seafloor spreading magnetic anomalies are symmetric with respect to the ridge axis between Ascension and St. Helena Islands, but the depth anomalies are quite asymmetric. The east side of the ridge axis is shallower $(\sim 1,000$ meters $)$ than the west side, probably as a result of a thermal upwelling of the lithosphere. We suggest that a mantle plume located on the African Plate, which could represent a larger swell linked to Ascension, St. Helena and Fernando Pó-Annobon Volcanic Lineament, might cause this type of anomaly.
\end{abstract}

Keywords: depth anomalies, magnetic anomalies, Ascension Island, St. Helena Island, South Atlantic.

RESUMO. Dados de batimetria de $12 \mathrm{kHz}$ e anomalias magnéticas do fundo oceânico foram empregados para calcular anomalias de profundidades na cordilheira mesoceânica entre as Ilhas de Ascensão e St. Helena. A profundidade teórica do fundo oceânico foi calculada com base no modelo de resfriamento de placas litosféricas e a idade crustal, considerando as anomalias magnéticas de expansão do fundo oceânico entre 0 e 25 Ma. Notamos que as anomalias magnéticas de expansão do fundo oceânico são simétricas em relação ao eixo da cordilheira entre as Ilhas de Ascensão e St. Helena. No entanto, as anomalias de profundidade são assimétricas com ao eixo da cordilheira. 0 lado leste da cordilheira é mais elevado ( 1.000 metros) do que o lado oeste, refletindo provavelmente uma subida da estrutura termal da litosfera sob esta região. Por esta razão, sugerimos a existência de uma pluma do manto localizada na Placa Africana, a qual se estenderia por uma grande região, envolvendo os complexos vulcânicos de Ascensão, St. Helena e Fernando Pó-Annobon e causaria uma elevação na estrutura termal da litosfera.

Palavras-chave: anomalias de profundidade, anomalias magnéticas, Ilha de Ascensão, Ilha de St. Helena, Atlântico Sul.

\footnotetext{
1 Universidade Federal Fluminense, Departamento de Geologia - LAGEMAR, Av. Litorânea s/n, sala 407, Gragoatá, 24210-340 Niterói, RJ, Brasil. Tel.: (21) 2629-5924; Fax: (21) 2629-5931 - E-mail: sidney@igeo.uff.br

2Universidade Federal Fluminense, Instituto de Física, Av. Litorânea s/n, Gragoatá, 24210-340 Niterói, RJ, Brasil. - E-mail: marisa@igeo.uff.br
} 


\section{INTRODUCTION}

According to the plate tectonics model the new oceanic lithosphere is formed at the spreading center along the mid-ocean ridges (e.g., Le Pichon, 1968). The upper layer of the oceanic crust generates seafloor spreading magnetic type anomalies that act as a magnetic tape recorder of the Earth's magnetic field as new crust is formed at the ridge axis (Vine, 1966). Thus, Heirtzler et al. (1968) showed that the age of the oceanic crust can be determined from seafloor spreading magnetic type anomalies.

Once it is formed the young oceanic lithosphere becomes colder and subsides as it moves away from the spreading center. It contracts and thus increases in density. Therefore, if we assume the oceanic regions to be compensated, the depth of the oceans should increase with increasing age (and thus plate density). For any model of the cooling lithosphere, the expected ocean depth can be calculated. Parsons and Sclater (1977) and many others (e.g., Stein \& Stein, 1992; Johnson \& Carlson, 1992; and Doin \& Fleitout, 1996) showed that the age of the oceanic crust can be used to derive theoretical seafloor depths from the cooling plate model. The parameters involved are determined by fitting a theoretical depth-age curve to empirical depth-age data believed to best represent the basin-wide thermal state of the lithosphere. Their simple model assumes a linear relation between the seafloor depth and the square root of crustal age, and, also between the heat flow and the inverse of the square root of the crustal age. Sclater et al. (1971) showed an empirical relation between heat flow and seafloor depth and the age of the oceanic crust.

Thus, the theoretical seafloor depths can be calculated from the age of the oceanic crust and used to indicate oceanic regions that agree or not with the cooling plate model. The seafloor depth anomalies, which mark the difference between the theoretical and observed seafloor depths, can be an indicative of the thickening of the oceanic crust due intense volcanism and/or of the location of the lithospheric thermal anomalies due to hotspots.

This paper examines the depth anomalies between the Ascension and St. Helena Islands (Fig. 1), which has been argued as a long ridge segment influenced by a ridge centered hotspot (e.g., Mello, 1993; Bruguier et al., 2003; Minshull et al., 2003). There are topographic and geochemical evidences that support a hotspot location in the region: (a) the existence of an anomalous topographic high at the ridge axis (e.g., Brozena, 1986) and (b) the isotopic spikes in the $\mathrm{La} / \mathrm{Sm}, \mathrm{Nd} / \mathrm{Zn}$ and $\mathrm{Sr} / \mathrm{Nd}$ ratios in basalts dredged around 100S (e.g., Schilling et al., 1985; Fontignie \& Schilling, 1996). However, there are strong geophysical evidences, such as: (a) an anomalous crustal thickness due to intense mantle upwelling underneath the region (e.g., Minshull et al., 1998) and/or (b) a large geographical extension of the hotspot. Thus, this work will focus on the analysis of the seafloor depth anomalies in the region to characterize the existence and extension of thermal anomalies between the Ascension and St. Helena Islands.

\section{Data set}

The bathymetric data from the GEODAS (GEOphysical DAta System) were used as observed seafloor depths. The GEODAS is an interactive database system developed by the National Geophysical Data Center (NGDC), which contains bathymetric (including multibeam), magnetic, gravity and seismic navigation data collected worldwide during marine cruises from 1953 to the present. Data sources include US, foreign oceanographic institutions and government agencies. Data quality depends on the accuracy of navigation systems, which is generally good from the 70's.

Figure 2 displays the GEODAS bathymetric track lines between the Ascension and St. Helena Islands. Ship surveys cover the region with more frequency in the interesting area, providing bathymetric data for generating 5 minutes grids and contour map (Fig. 3) all from standard GMT programs (Wessel \& Smith, 1998).

The magnetic anomalies obtained from aeromagnetic surveys performed by the Naval Research Laboratory (NRL) during the Centratlan Project (Brozena, 1986) were used to depict the age of the oceanic crust (Fig. 4a). The synthetic magnetic model by Mello (1993) was handy to match the observed seafloor spreading magnetic type anomalies (Fig. 4b). He used the geomagnetic time scale published by Cande \& Kent (1995), assuming a magnetic layer of $1 \mathrm{~km}$ with a standard magnetization of $0.02 \mathrm{emu} / \mathrm{cm}^{3}$ at the ridge axis. Thus, the magnetic lineations in Figure 4a represent, in fact, a given seafloor age $(t)$ that was used to calculate the theoretical seafloor depths.

\section{Calculation of theoretical seafloor depths and seafloor depths anomalies}

The theoretical seafloor depth $(d)$ from Parsons \& Sclater (1977) assumes that the ridge axis is infinity in the y direction and the temperature of the plate is constant in the same direction. Thus, the theoretical seafloor depth is calculated by the following equation:

$$
d=d_{r}+\frac{2 \rho_{a} \alpha T_{a}}{\left(\rho_{a}-\rho_{w}\right)} \sqrt{\frac{k t}{\pi}}
$$

where $\rho_{a}$ is the density of the asthenosphere $\left(3.3 \times 10^{3} \mathrm{~kg}\right.$ $\left.\mathrm{m}^{-3}\right), \rho_{w}$ is the sea water density $\left(1.05 \times 10^{3} \mathrm{~kg} \mathrm{~m}^{-3}\right), \alpha$ is the 


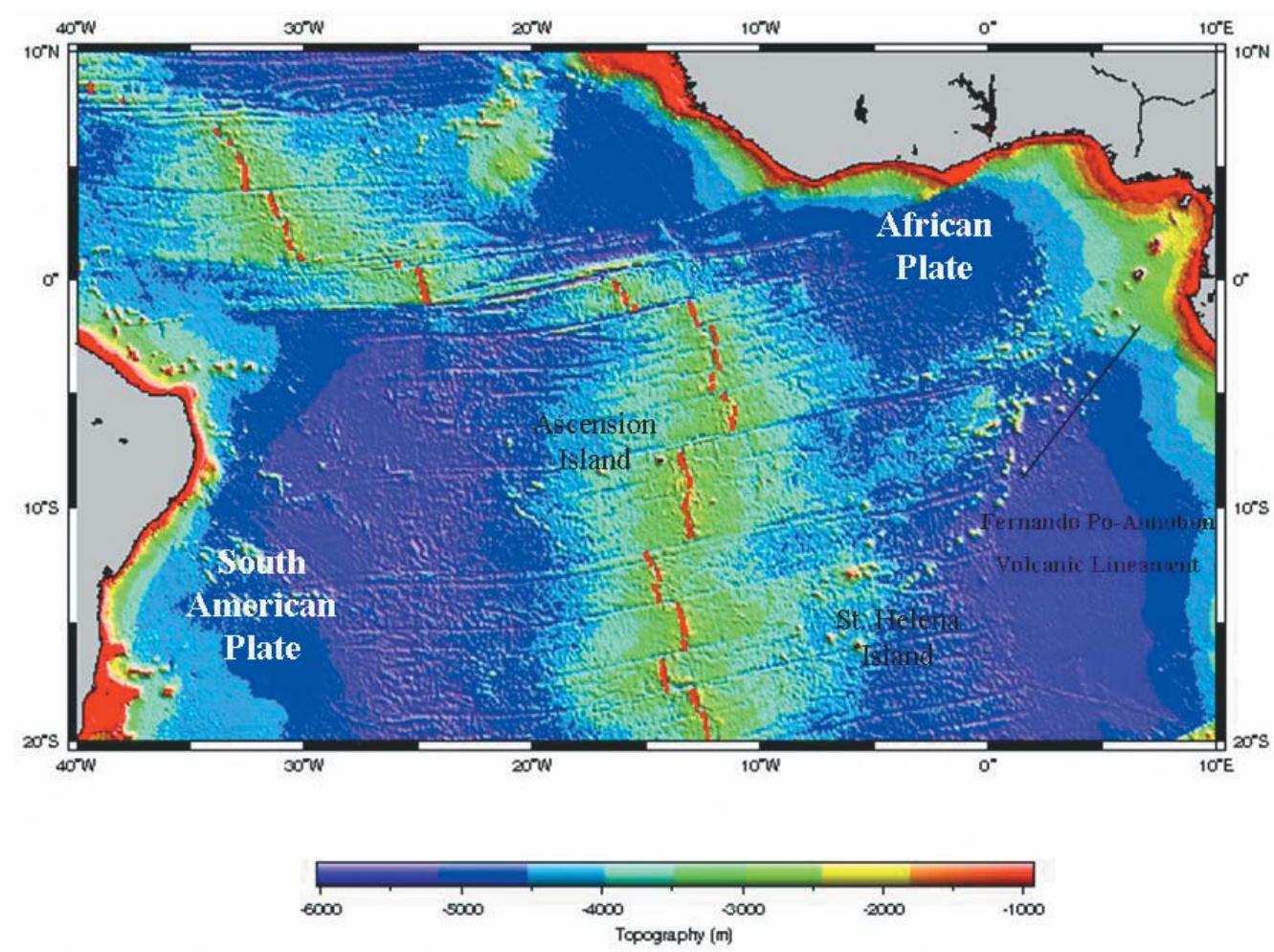

Figure 1 - Location of the study area showing the location of the spreading axis (red line), as well as Ascension and St. Helena Islands and Fernando Pó-Annobon Volcanic Lineament in the South Atlantic. Bathymetric map based on ETOP02 data, National Geophysical Data Center (NGDC).

thermal expansion coefficient $\left(3 \times 10^{-5} \mathrm{C}^{-1}\right), k$ is the diffusivity $\left(10^{-6} \mathrm{~m}^{2} \mathrm{~s}^{-1}\right), T_{a}$ is the temperature of the base of the lithosphere $\left(1200^{\circ} \mathrm{C}\right)$ and $d_{r}$ is the average water depth at the ridge axis $(2.5$ $\mathrm{km})$, which was assumed empirically observing the depths of the mid-ocean ridge crests throughout the globe.

Thus,

$$
d=2.5+0.33 \sqrt{t}
$$

where $d$ is in $\mathrm{km}$ and the seafloor age $(t)$ in Ma.

The theoretical seafloor depth $(d)$ was calculated for each age $(t)$ from the magnetic lineations in Figure 4a. These data provided a 5 minute depth grid as a function of age. Subtracting this theoretical seafloor depth grid from the observed seafloor depth grid, we finally obtained the seafloor depth anomaly map, which is displayed in Figure 5.

\section{Data interpretation}

In Figure 3 the ridge morphology is essentially symmetric with respect to the ridge axis. The Ascension and Bode Verde fractures zones are the main ridge axis discontinuities within the region, which display right-lateral offset of the order of tenths of kilometers. A rift valley about 3,000-3,500 $\mathrm{m}$ deep is observed everywhere along the ridge axis between Ascension and St. Helena Islands, but it disappears between $8^{\circ}$ and $10^{\circ} \mathrm{S}$, where there is an anomalous axial high of about $2,500 \mathrm{~m}$ that is associated to remarkable volcanic edifices off-axis. In particular, this region is assumed to be the result of a ridge centered hotspot, somehow linked to the Ascension Island (e.g., Brozena, 1986).

The magnetic anomalies are also symmetric to the ridge axis, extending from 0 to approximately $25 \mathrm{Ma}$, as shown by magnetic lineations in Figure 4a. Since each anomaly lineation (isochron) was formed at the ridge axis, each lineation represents the former site of spreading and, therefore, shows the tectonic framework along the time past. The central magnetic anomaly (zero age) fits the rift valley where it exists, while all major offsets of the central magnetic anomaly represent the ridge axis discontinuities of different orders.

The theoretical seafloor depth as a function of age mainly reflects the thermal subsidence of the oceanic lithosphere, especially at mid-ocean ridges where subsidence due to sedimentation is not significant. It also reflects the decay of the heat flow away from the ridge crest and the decay of magnetization due to the co- 


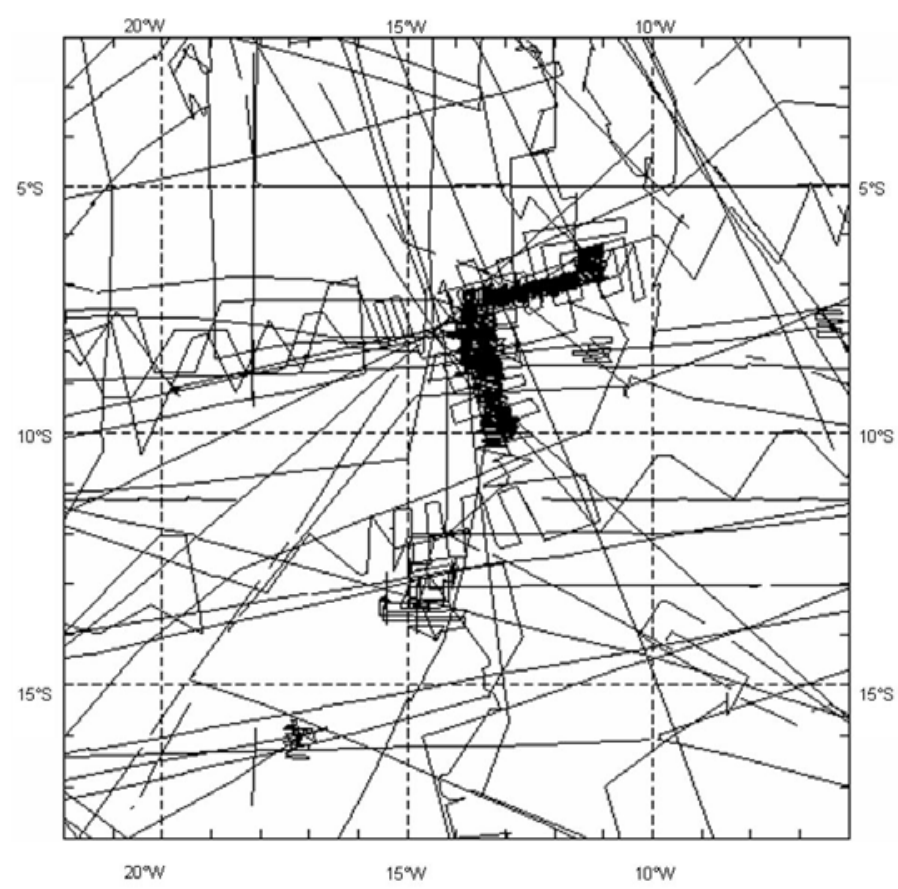

Figure 2 - Track lines of bathymetric surveys from the GEODAS database.

oling of the magnetic layer as well (e.g., Pariso \& Johnson, 1993). However, Figure 5 shows that the observed seafloor depth on the African Plate is about $1,000 \mathrm{~m}$ shallower than theoretical seafloor depth, showing a higher topography over several hundred of kilometers, which do not fit the theoretical curve.

Figure 5 also shows a striking asymmetry in depths. The east side of the ridge axis is shallower than the west on the order of $1,000 \mathrm{~m}$. This extends beyond the seamounts on the east side of the ridge, causing a large depth anomaly, probably associated to off-axis hotspot. In fact, this anomaly could be linked to a further south depth anomaly around the region of St. Helena Island. If it is so, Ascension and St. Helena Island as well as many volcanic edifices within this region, including the ridge axis, can be a result of a mantle swell that extends for many kilometers up to the Fernando Pó-Annobon Volcanic Lineament near the African Margin, as we see in Figure 6.

\section{CONCLUSIONS}

The formation of a new oceanic lithosphere is usually modelled as a symmetric process with respect to the spreading axis. But, the thermal structure of the lithosphere underneath the African Plate is distinct from the South American Plate around the Ascension and St. Helena Islands (Fig. 6). The shallower depth anomalies observed on the east side of the ridge axis between the Ascension and St. Helena Islands is an evidence of an off-ridge axis hotspot located on the African Plate (Figs. 5 and 6). This hotspot may actually represent a topographic swell due to a deep mantle anomalous source, which extends to the south to St. Helena and to the east to the African Margin. Rocks collected at the ridge axis between Ascension and St. Helena Islands result from a plume type mantle (e.g., Fontignie \& Schilling, 1996). Geochemical detailed rock analysis of Ascension region and St. Helena should prove a close origin of the mantle source and the same origin of the topographic swell.

Further study on the depths anomalies over a wider region in the South Atlantic is also suggested in the light of South Pacific studies on Super Swells (e.g., Adam et al., 2005). This should contribute to examine depth anomalies in South Atlantic as well as mantle plumes.

\section{ACKNOWLEDGMENTS}

We thank the Fundação de Estudos do Mar (FEMAR) for supporting Marisa Makler at LAGEMAR-UFF. The program CAPESCOFECUB (Project 415/03) has helped to carry on cooperative research in South Atlantic. In different phases of this work, we used the Generic Mapping Tools - GMT (version 3.3.4), Wessel \& Smith (1998). 


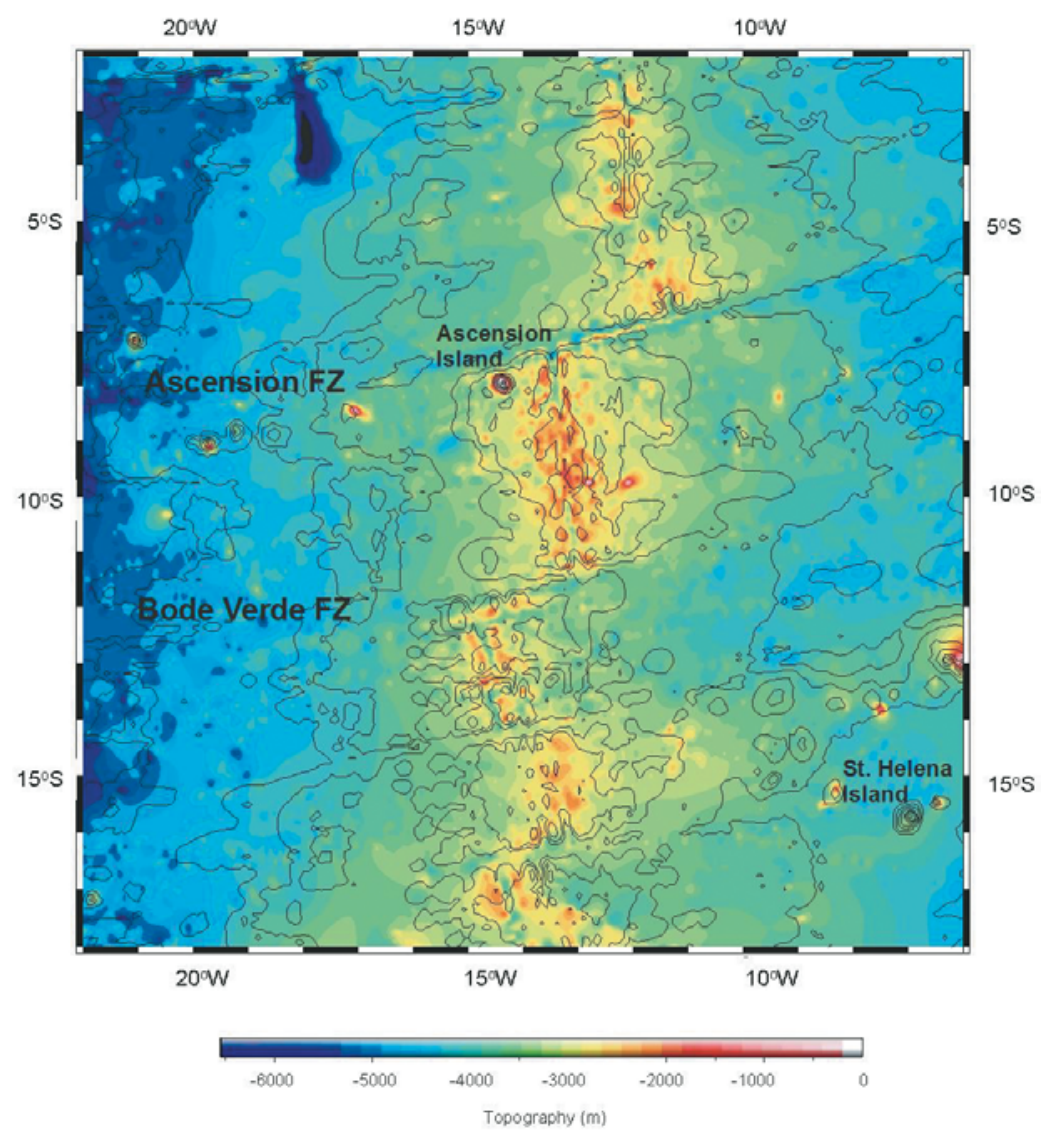

Figure 3 - Observed seafloor depths shown by a coloured bathymetric map derived from 5 minute grid from the GEODAS database. Contour lines are in $1 \mathrm{~km}$ interval. Main islands and fracture zones are displayed.

\section{REFERENCES}

ADAM C, VIDAL V \& BONNEVILLE A. 2005. A method to characterize seafloor swells with application to the south central Pacific. Geochemistry Geophysics Geosystems, 6, Q01003, doi:10.1029/2004GC000814.

BROZENA JM. 1986. Temporal and spatial variability of seafloor spreading processes in the Northern South Atlantic. J. Geophys. Res., 91: $497-510$.

BRUGUIER NJ, MINSHULL TA \& BROZENA JM. 2003. Morphology and tectonics of the mid-Atlantic ridge, $7^{\circ}-12^{\circ} \mathrm{S}$. J. Geophys. Res., 108: 2093-2115, doi:10.1029/2001JB001172.

CANDE SC \& KENT DV. 1995. Revised calibration of the geomagnetic polarity timescale for the Late Cretaceous and Cenozoic. J. Geophys. Res., 100: 6093-6095.

DOIN MP \& FLEITOUT L. 1996. Thermal evolution of the oceanic lithosphere: an alternative view. Earth Planet. Sci. Lett., 142: 121-136.

FONTIGNIE D \& SCHILLING J-G. 1996. Mantle heterogeneities beneath the South Atlantic Ridge. Geophys. J. Ast. Soc., 20: 271-284.
HEITZLER JR, DICKSON GO, HERRON EM, PITMAN III WC \& LePICHON X. 1968. Marine magnetic anomalies, geomagnetic field reversals, and motions of the ocean floor and continents. J. Geophys. Res., 73: 21192136.

JOHNSON HP \& CARLSON RL. 1992. Variation of sea floor depth with age: a test of models based on drilling results. Geophys. Res. Lett., 19: 1971-1974.

LE PICHON X. 1968. Sea-floor spreading and continental drift. J. Geophys. Res., 73: 3661-3697.

MELLO SLM. 1993. Marine Geology and Geophysics of the Mid Atlantic Ridge Between Ascension and Sta. Helena Islands. Master Dissertation, Universidade Federal do Rio de Janeiro/IG - Depto de Geologia, RJ, $90 \mathrm{pp}$.

MINSHULL TA, BRUGUIER NJ \& BROZENA JM. 1998. Ridge-plume interactions or mantle heterogeneity near Ascension Island? Geology, 26: $115-118$.

MINSHULL TA, BRUGUIER NJ \& BROZENA JM. 2003. Seismic structure 


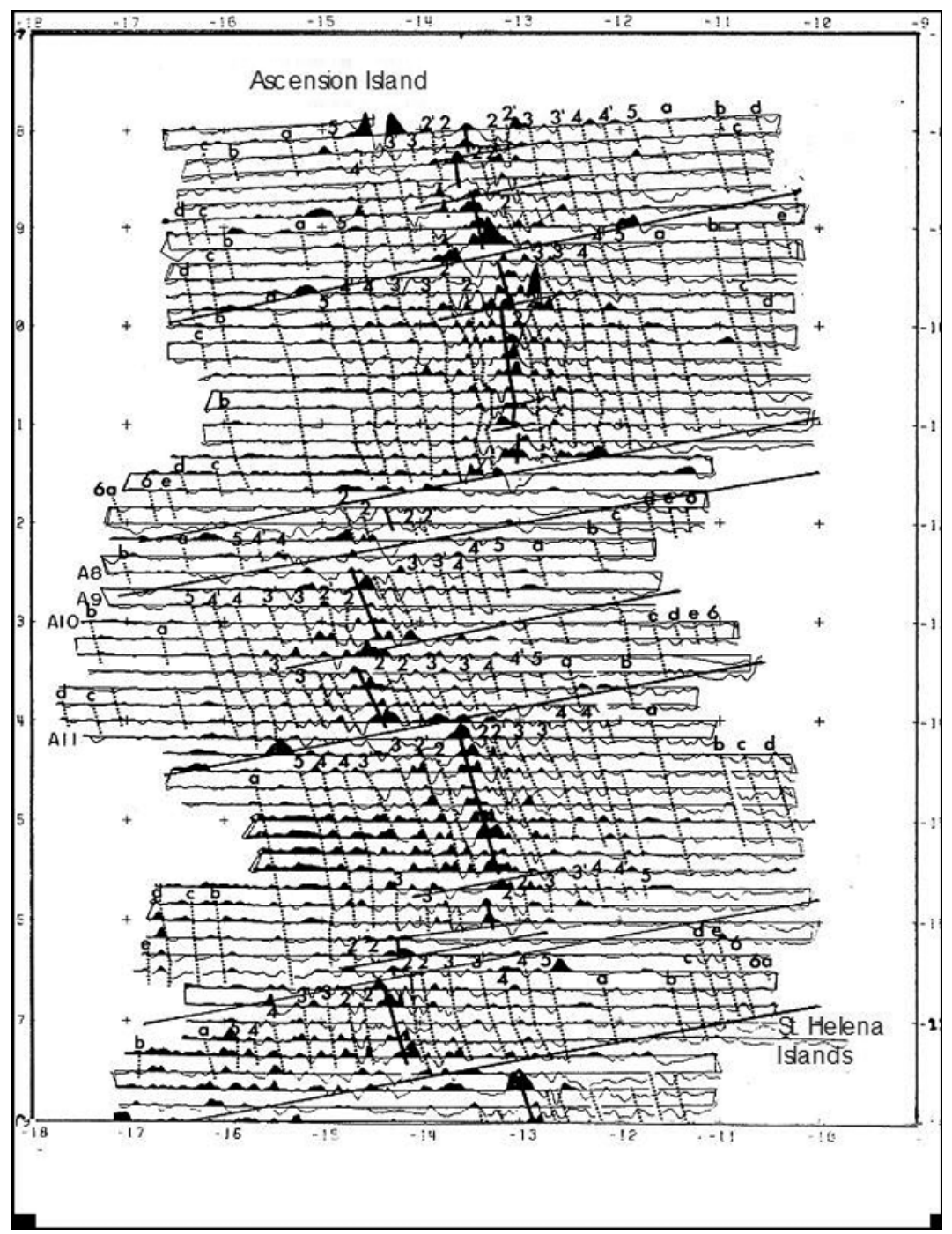

Figure 4a - Map of seafloor magnetic anomalies between Ascension and St. Helena Islands. Magnetic lineations (dashed lines) are approximately in the north-south direction and parallel to the ridge axis (solid black line). Major offsets (almost east-west solid black line) represent ridge discontinuities.

of the Mid-Atlantic Ridge, 8 - $9^{\circ}$ S. J. Geophys. Res., 108: 2513-2535, doi: 10.1029/2002JB002360.

PARISO JE \& JOHNSON HP. 1993. Do layer 3 rocks make a significant contribution to marine magnetic anomalies? In situ magnetization of gabbros at ocean drilling program hole 735B. J. Geophys. Res., 98: 16033-16052.

PARSONS B \& SCLATER JG. 1977. An analysis of the variation of ocean floor bathymetry and heat flow with age. J. Geophys. Res., 82: 803-827.

SCHILLING J-G, THOMPSON G, KINGSLEY R \& HUMPHRIS S. 1985. Hotspot-migrating ridge interaction in the South Atlantic. Nature, 313: 187-191.
SCLATER JG, ANDERSON RN \& BELL ML. 1971. Elevation of ridges and evolution of the central eastern Pacific. Jour. Geophys. Res., 76: 7888-7915.

STEIN C \& STEIN S. 1992. A model for the global variation in oceanic depth and heat flow with lithospheric age. Nature, 359: 123-128.

VINE FJ. 1966. Spreading of the ocean floor - New evidence. Science, 154: 1406-1415.

WESSEL P \& SMITH WHF. 1998. New, Improved Version of Generic Mapping Tools Released. EOS Trans., AGU, 79(47): p. 579. 

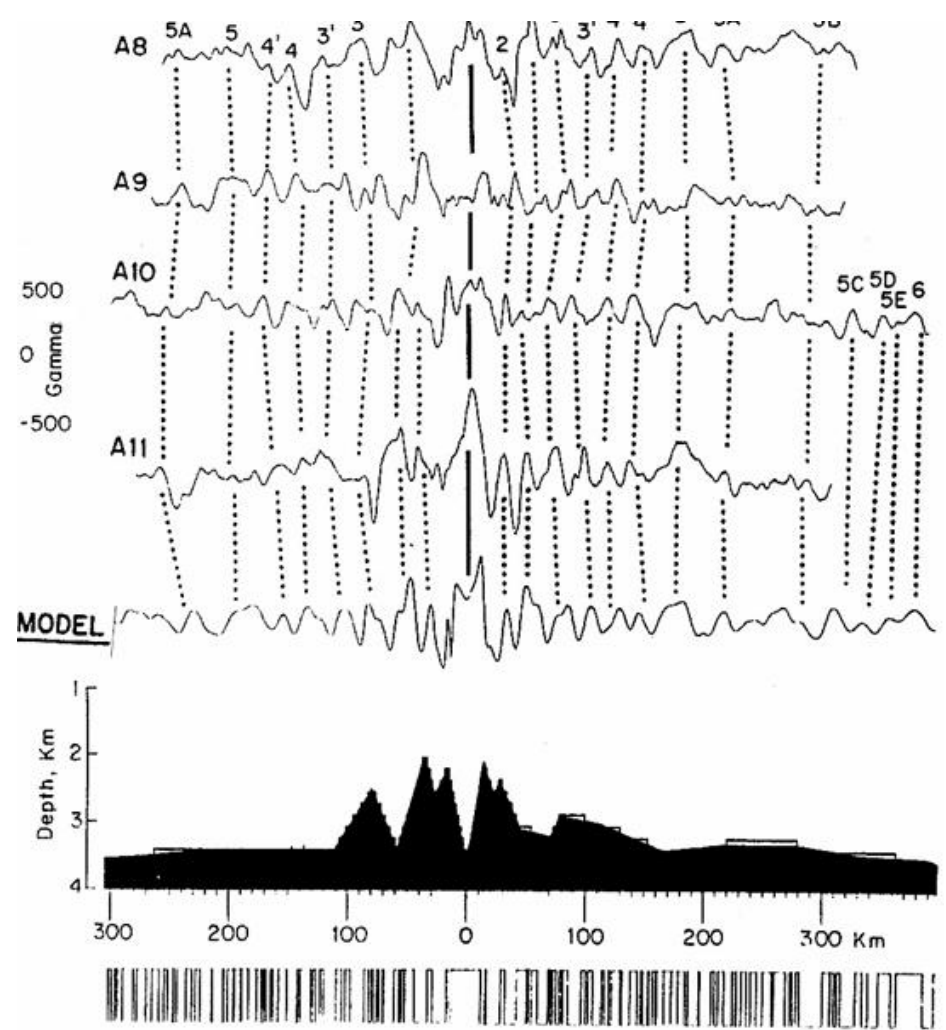

Figure $\mathbf{4 b}$ - Synthetic model by Mello (1993) used to match the observed magnetic profiles across the ridge crest segments between Ascension and St. Helena Islands.

\section{NOTES ABOUT THE AUTHORS}

Marisa Makler. Born in Niterói (RJ), Marisa is 24 years old with a Bachelor of Physics from Universidade Federal Fluminense (UFF). She is currently studying Marine Geology and Geophysics at LAGEMAR (Laboratório de Geologia e Geofísica Marinha). She works for Landmark/Halliburton as a member of Seismic processing Team.

Sidney Luiz de Matos Mello. Born in Campos dos Goytacazes (RJ), Sidney has been working for Universidade Federal Fluminense (UFF) since 1985. Over the past 21 years he as held several positions within the University. These positions include: Director of Geology, Dean of Research and his current position, Dean of Academics. Upon completion of his Bachelor of Geology at Universidade Federal do Rio de Janeiro (UFRJ), he stayed on to study a Masters of Geology with cooperation from Lamont Doherty Earth Observatory, at Columbia University (NY). He also holds a PHD in Marine Geophysics from Leeds University in Great Britain and Post Doctorate from Université de Bretagne Occidentale, in Brést, France, where he is still a visiting Professor. 


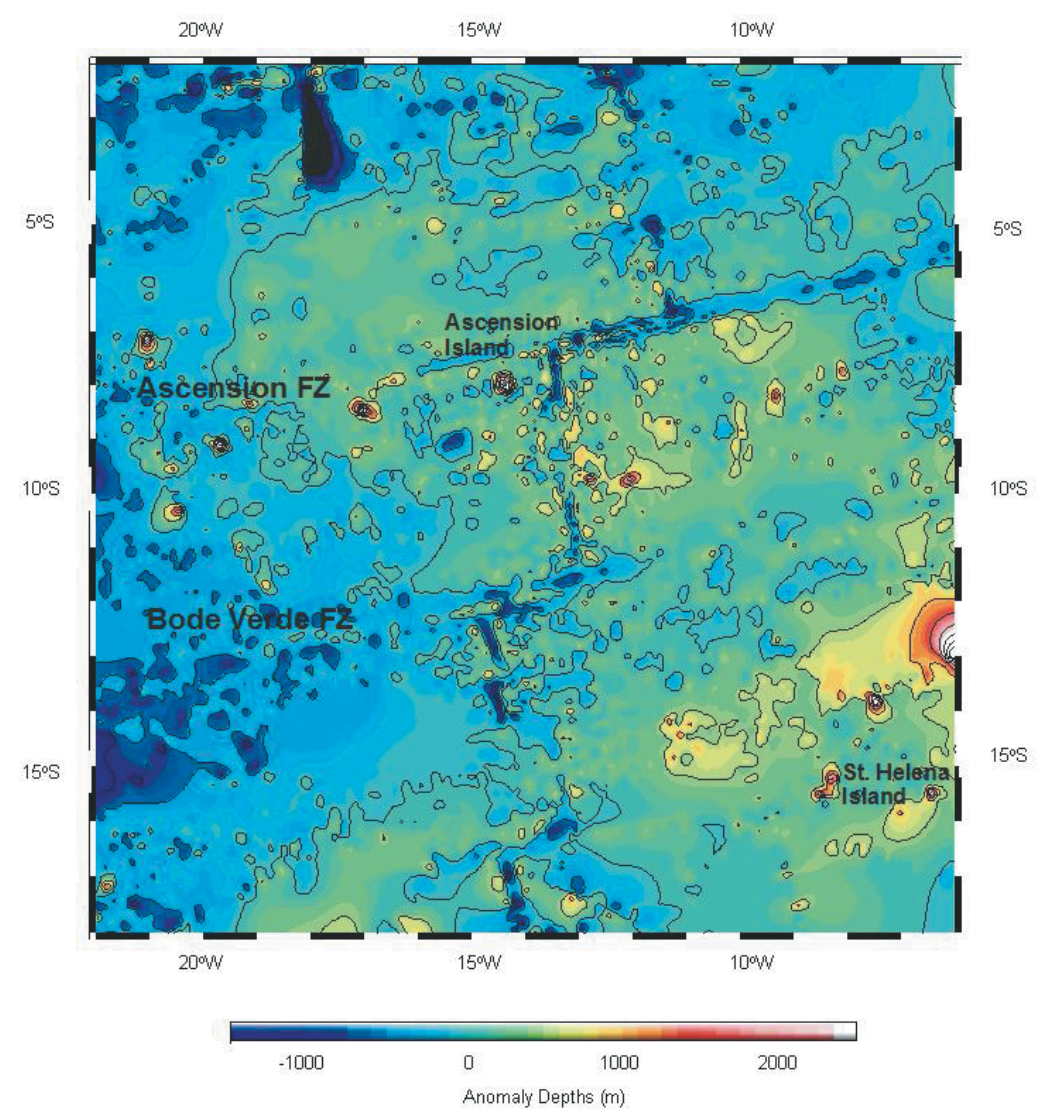

Figure $\mathbf{5}$ - Seafloor depth anomaly map calculated from the subtraction of the observed and theoretical seafloor depth. Main islands and fracture zones are displayed.

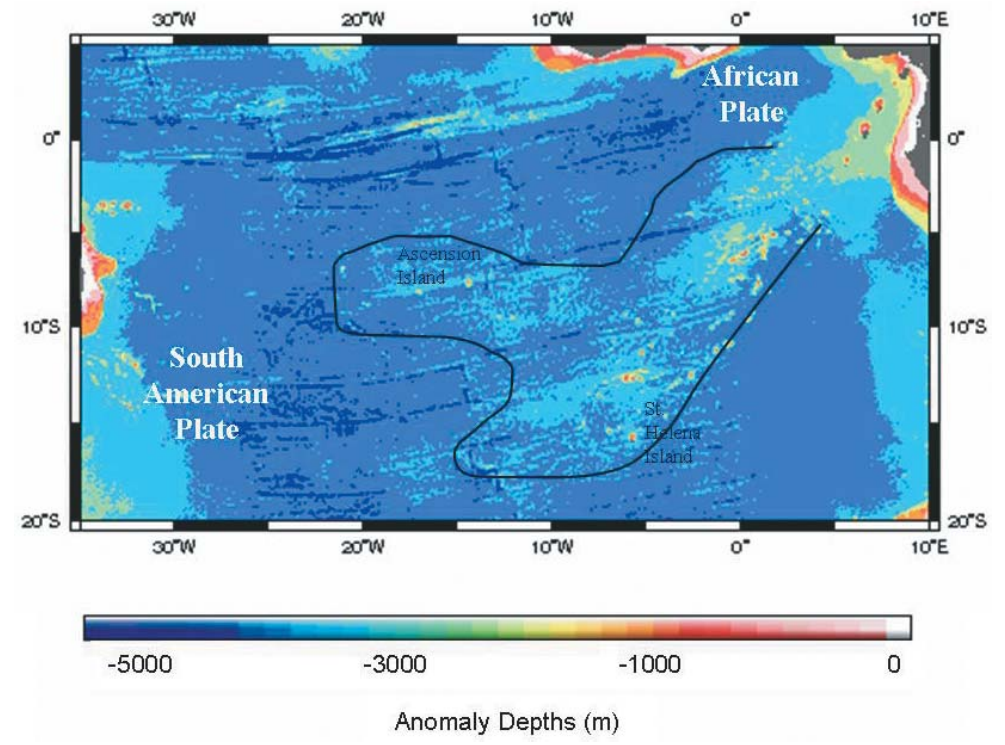

Figure 6 - Seafloor depth anomaly map between Ascension and St. Helena Islands (South Atlantic) calculated from the subtraction of the observed and theoretical seafloor depth for a larger area. Main islands, fracture zones and the Fernando Pó-Annobon Volcanic Lineament are displayed. Encircled area is suggested to be a large topographic swell. 